\title{
Stuttering: Can Research Unravel The Riddle?
}

\author{
M. Marks Wahlaus, MA (Log) (Witwatersrand) \\ Department of Speech Pathology and Audiology \\ University of the Witwatersrand, Johannesburg
}

\begin{abstract}
In spite of decades of research on stuttering there are few unequivocal findings. Several reasons for this are offered and discussed. Particular attention is paid to the lack of one accepted definition of stuttering. Other issues concern the unit of stuttering, inter-and intra-stutterer variability, the overt and covert features of stuttering, objective and subjective measures in stuttering research and the sampling of material for study. These are some of the problems which pertain to study of the nature of stuttering. They apply also to research on therapy, which presents additional challenges to the researcher.
\end{abstract}

\section{OPSOMMING}

Ten spyte van dekades van navorsing oor hakkel. is daar weinig onomwonde bevindings. Verskeie verklarings vir hierdie verskynsel word verskuf en bespreck. Spesifieke aandag word geskenk a an die gebrek van een aunvaarde definisie van hakkel. Ander geskilpunte wat bespreek word is dic cenheid van hakkel, inter-en intra-hakkelvariasie, die overte en koverte kenmerke van hakkel, objektiewe en subjektiewe metings wat in hakkelnavorsing a angewend word en die keuse van spraakmonsters wat bestudeer word. Hierdie is sommige van die probleme in die studic van die aard van hakkel. Dit is ook van toepassing op navorsing oor terapie. wat addisionele tuitdagings aan die navorser bied.

The phrase "the riddle of stuttering" coined by Bluemel in 1937 has been frequently quoted to denote the manifold difficulties concerned with stuttering. Van Riper questions it as being simplistic:

"We do not like the term because it implies a pat verbal answer and because it fails to do justice to the complexity of the disorder.

Stuttering is more than a riddle. It is at least a complicated multidimensional jigsaw puzzle, with many pieces still missing."

Van Riper (1982), p. 1

To those working with this difficult disorder, it seems that it might well be described in the way Winston Churchill explained Russia in 1937 as "a riddle wrapped in a mystery inside an enigma".

The lack of final answers is in no way due to a paucity of research efforts. Curlee \& Perkins (1984) summing up the status of understanding of stuttering in the middle of the 1980 's believe that "After so many years and so much work, it may seem somewhat discouraging that our knowledge base on stuttering will rarely support unequivocal inferences or conclusions." (Preface). This theme is continued by Perkins' carpenter analogy where he likens the observations about stuttering to individual pieces of lumber lacking the final design to give meaning to them (1985), and by other contemporary writers such as Zimmerman, who as recently as 1984 talks in terms of the "lack of progress in coming to an understanding of stuttering and its treatment."(1984, p. 131), echoing an earlier stated view that there was a need for a unifying conceptual framework of stuttering (Zimmerman et al. 1981).

There are still no definitive answers to the questions - What is stuttering? What causes it? What is the cure (a word which therapists still eschew)? These are the naive, but basic verbalizations of the issues which have constantly plagued speech therapists and the stutterers with whom they work.

It is the belief of the writer that the first of these questions is the most fundamental, and the answer to it the sine qua non. The other areas, those of cause and treatment, are dependent on it. If research cannot determine or uncover what stuttering is, it is axiomatic that there can be no more than speculation about its cause or causes; if any etiological factors are presumed, it is important to know on which of the facts, or observations, about stuttering they are made, and how far the jump had to be made before the causal conjecture was made. As far as remediation is concerned, the results of therapy for a condition which cannot be absolutely defined,cannot be absolutely predictable - "What stuttering is and what can be done to bring about its modification are inexorably linked together" (Brutten 1975, p. 201).

The "facts" about stuttering are the proven data. Most of these have been derived from rigorously controlled studies, which are valid, reliable and replicable. It is the view of the writer that these data are scarce. For the few studies which give positive results, there are many which purport to test the same aspects, yet produce contradictory findings.

To the question of why research on stuttering has not provided definitive facts, many answers may be mooted. Adams (1976) discussed some common problems in the design and 
conduct of experiments in stuttering when he considered what he described as circular definitions of hypothetical constructs, operational definitions that lack denotative specificity, research methods based on invalid assumptions about stuttering and omitted or inappropriate measurement of speech rate in operant studies of stuttering ( $p$ p. 3-9). His thinking on these problematic issues, many of which are still unresolved, is acknowledged.

It is the purpose of this paper to suggest some possible reasons why results of research on stuttering are so conflicting, and why findings of what is ostensibly the same aspect are often so disparate. The discussion centres around the nature of stuttering, and stresses the issue of definition.

\section{DIFFICULTIES IN DEFINING STUTTERING}

To the intelligent but naive observer it must be puzzling to find that what is an articulation defect is an articulation defect (or was, before the head of phonology emerged from the linguistic waters); that what is cleft palate speech is cleft palate speech; but that what is stuttering, is not necessarily, or not always, stuttering.

The literature abounds in non-confirmed or contradictory findings. While these are often attributed to individual differences between stutterers, or to the concept that there may be different sub-groups of stutterers, much of the conflict and confusion has as its genesis the fact that there is not unanimity among researchers as to what constitutes stuttering. To date, there has not been one definition which has received universal acceptance. The direct relationship between understanding the nature of an event and being able to define it is self-evident. If authorities do not agree about what stuttering is, it is little wonder that results of studies conflict. If there is not common cause as to what constitutes stuttering, workers may be studying different things and considering them the same.

The fact that, after all the years of investigation and theorizing, there is no one accepted definition of stuttering which appears to this writer to be the most dominating reason for the disparity in research findings, and for the lack of conclusions. If one researcher takes as his operational definition (and that concept brings its own hazards) that stuttering is present if a speaker repeats, another says that stuttering is present if the speaker repeats or prolongs and yet another that stuttering is present if the observer says it is, each will interpret the findings of the identical study in a different way, and come to different conclusions about the results.

It would be surprising if, over the years, some definitions did not become more accepted than others. The definitions which seem to have withstood some tests of time are those implied in Johnson's description of types of nonfluencies (1961) and Wingate's "standard" definition (1964). It is probable that these have been used in research because of their purely descriptive nature. A researcher can relate to terms such as wholeor part-word repetitions (Johnson 1961), and “... audible or silent repetitions or prolongations in the utterance of short speech elements, namely: sounds, syllables, and words of one syllable." (Wingate, 1964), (even though there can, and has been controversy over the term "voluntary" which he uses to preface this description). It is easier to mark a sound, syllable or word as being stuttered on with this directive in mind, than it would to mark a word "improperly patterned in time" (Van Riper, 1963).
That there are problems concerning definition is not new. Van Riper explains some of the different concepts underlying the various definitions. By virtue of the insights he gives, his views are given verbatim:

"Some of the definitions are merely statements of the authors' points of view with respect to the cause or nature of the disorder ... Some definitions are so broad that they fail to provide proper limitations... Conversely, there are definitions which are so restrictive that they exclude many persons who would be commonly called or would call themselves stutterers... Other definitions are frankly descriptive lists of behaviors, overt and covert, shown by different stutterers... Finally, there are the definitions consisting of descriptions of phenomena which seek to identify the essential speech characteristics that differentiate stuttering behavior from other phenomena with which it could be confused."

Van Riper (1982), pp. 11-12

It is the opinion of the writer that many of the problematic issues surrounding definition of stuttering can be dealt with within the frame of the molecular approach to stuttering as espoused by Brutten \& Shoemaker (1967) and Brutten (1975). It would seem that a detailed description of the observable behaviours which constitute stuttering would go far in lessening the confusion. This view endorses Wingate's (1964) opinion:

"Any definition of stuttering which treats inadequately with speech characteristics contains a serious fault, for such features are the sine qua non of stuttering... It seems evident that, in essence, we must be content for some time to come with a 'phynotypic' definition of stuttering; that is, a definition which sticks to observable facts about stuttering and excludes hypothetical predilections. It seems to me that a definition such as this is prerequisite to pursuing further rational and reasoned inquiry into the nature of the disorder."

Wingate (1964), p. 484-485

Several experimenters have paid attent ion to this issue. Adams (1976) considered that it was necessary to conceive of specific behaviours, stating that "... it seems reasonable to assert that phrases like a moment or instance of stuttering are virtually useless to the researcher interested in replications..." Believi ing that "So long as precision and replication remain integral parts of scientific and scholarly inquiry, general' and vague definitional terminology ought to be avoided" (pp. 4-5).

From the foregoing discussion, it can be seen that lack of concensus about a definition of stuttering reflects researchers' diversity of perceptions about the nature of stuttering; and that what one investigator considers to be a stuttering event may not be a stuttering event for another investigator. This lack of agreement about the most basic issue - that which is to be studied - seriously hampers the advancement of knowledge based on scientific study.

\section{THE UNIT OF STUTTERING}

Allied to the previous discussion of definition is the issue of what comprises the unit of stutering. It has been relatively easy to assume that a person is stuttering on a word, and most research is carried out with this assumption. This has come to be questioned by observant clinicians, and by research fin- 
dings that the fluency of stutterers can be different to that of non-stutterers. The writer has questioned whether the unit of stuttering is, indeed, the word, or whether the stutter is waiting, beneath insecure thency "like Garp's 'undertoad' "to arrest the stutterer (Marks Wahlhaus, 1986).

Wingate (1986) asks whether words per se represent the true focus of stuttering occurrence appropriately. He feels that saying that stuttering occurs on words ".... or even in relation to words ..." is essentially a surface description which reflects what he considers to be only a first level of observation. He acknowledges that we have been limited to this descriptive reference, and should be cognizant of the limitations (p. 25).

The fact that researchers are not sure, not only of what the stutter is, but where it is, provides another area of potential misunderstanding among researchers.

\section{INTER- AND INTRA-STUT'TERER VARIABILITYY}

If there is one feature which either implicitly or explicitly dogs the footsteps of experimenters, it is that of individual differences between stutterers. Hard on its heels, is the factor of intrastutterer variability. Researchers attempt to cope with these problems in different ways.

In group design studies there are often attempts to limit variability by, for example, excluding female stutterers, or using the same proportion of male to female stutterers which are reported in the general population. Some investigators restrict the age range of their subjects, other intelligence, others family history. A factor which is often controlled for is that of severity. Attempts are often made to introduce different types of controls, depending on the variables to be studied. Some researchers feel confident in generalizing their findings from a large number of subjects. Taking individual differences into consideration, a caveat regarding generalizing must always be recognized.

An alternative to group study design is the single subject, or single subjects, design. This has received scientific status within the behavioural sciences? having been given particular impetus with behaviour modification studies. With these designs, the researcher is able to control for the inter-subject variability, but has to take cognisance of the differences within the same subject. This is of particular relevance to stuttering where, for example, adaptation has to be taken into consideration when stuttering change is examined, or when a subject's mood changes have to be controlled for before the effects of a treatment can be assessed (A'ron, 1964). Working within this structure. researchers are explicitly aware of their inability to generalize from their results. There does, however, seem no doubt that detailed study of one, or of a series of idividuals, adds to the corpus of knowledge on stuttering.

When intra-subject investigations are considered, it is of value to keep in mind the question of consistency. Studies have been directed to finding out more about the tendency of stutterers to stutter on the same word as on a previous utterance or reading. The writer found the advanced stutterers which she studied longitudinally to have behavioural consistency over time (Marks Wahlhaus, 1990). Nevertheless, investigators should take into consideration that there is variation in a stutterer's speech under different conditions, and that findings about the nature of the one person's speech could differ form one time to the next, depending on the conditions of testing.

\section{OVERT' AND COVERT' FEATURFS OF STUTTERING}

In his text on the nature of stuttering, Van Riper (1982) uses the term "phenomenology" to introduce two chapters, the one being further detailed in terms of "overt features" and the other, "covert reactions". Many speech pathologists would disagree with Wingate's (1964) relegation to a subsidiary status of his definition of associated features, "... of a more or less general or vague nature which include such things as indications or report of excitement, tension, personal reactions, feelings of attitudes." (p. 488). Exclusion of covert reactions in research on stuttering is not always considered as desirable, and studies have been oriented towards the facet only, not only within the field of speech pathology, but in allied disciplines such as psychology. Defining and controlling these less tangible variables present particular difficulties when conducting research in this area, with particular difficulties inherent in measurement systems. It seems that the safeguard which should be taken is an explicit awareness of the subjectivity of these features.

\section{OBJECTIVE AND SUBJECTIVE MEASURES IN STUTTERING RESEARCH}

Measurement in behavioural research is fraught with difficulties. With developing technologies, objective measures are becoming more viable. At times objectivity is gained at the expense of meaningfulness. Glottographic findings of laryngeal function may prove to be of interest in terms of physiology and possibly etiology, but do not contribute significantly to the applied aspect of speech therapy. Core findings about the nature of stuttering cannot be overestimated; however, the researcher must recognise the level of his research, and the practical implications and applications of it.

The more tried and tested means of assessing and describing stuttering are those which involve some type of human judgement. Many considerations have to be made when this type of assessment procedure is used in stuttering research.

Some of these involve the number of judges, their professional or lay standing. their experience with stuttering which can involve the question of training. There are conflicting ideas in the research reports concerning the way judge agreement should be assessed, taking into account the varied results of inter-and intra-judge agreement under different conditions of experimentation, as well as different statistical procedures to establish agreement (Marks Wahlhaus, 1979, 1990).

Motivated decisions have to be made as to the presentation of the material to the judges. These include such objectives as to whether this is to be done visually, auditorally, or both whether the stutters are to be considered in isolation or in the speech context; whether the judging situation is to be rigorous ly experimental or more clinical, among others.

Attention is drawn here to these aspects, as the writer believes that if these important considerations are not taken into account, results of studies involving judges cannot be compared or collated, and that failure to control for these factors can compound the confusion of findings of studies which purportedly examine the same aspects, but in fact, do so in different ways. 


\section{SAMPI,ING OF MATERIAL FOR SIUDY}

A factor which needs to be taken into account when studies are carried out on stuttering, is the source of the stuttering data. Clinical experience has shown that many stutterers show differing severity when they read and when they speak; from a molecular point of view, therapists observe that some behaviours can be present in one condition and not in the other. Yet, very many studies use stutters collected from a corpus of read material (understandably, as the reading situation is more easily controlled than conversation), and explicitly or implicitly identify these with the "stutterer's speech".

Even more marked than the difference between speaking and reading, is the clinically realised difference between both of these and many stutterers' speech performances when under stress, for example, when talking on the phone. Van Riper (1982) discusses at some length his observations and views of the way speech is disrupted by stress, within the context of his view of stuttering as a disorder of timing (pp. 437-443), but there is little experimental evidence on this issue. It would be of interest to study specifically the stuttering behaviours manifested by speakers while talking under this type of stress, particularly to see if the same behaviours are present in all situations but more frequently in the stressed situation, or if different and more bizarre responses are evidenced when the stutterer is faced with a situation which has more difficult communication demands. As part of a larger study, the writer studied this aspect and found that, in several instances, the telephone situation did indeed evoke more abnormal beha. viours than were evidenced in speaking or reading (Marks Wahlhaus, 1990).

Another aspect which should receive more experimental attention is the varied way in which a person stutters on words beginning with different phonemes. As has been pointed out above, recent thinking is challenging the concept that stuttering is necessarily "on" words, or even sounds. Until it is proved that word beginnings and initial phonemes are not the stuttering focus, attention must be paid to them. Clinical experience has demonstrated that many stutterers manifest different behaviours depending on the articulatory and phonatory features of individual sounds. As early as 1935 Johnson \& Brown reported on stuttering in relation to various speech sounds (1935), as did Brown (1938), in one of his often-quoted studies. These studies gave rise to theoretical speculation concerning the reason for the influence of various sounds on stuttering, but there has been little definitive research on this topic. A particular lack is noted within the molecular framework, which seems particularly suited for an investigation of this type. If different behaviours are manifested with the production of words beginning with different phonemes, this cannot be ignored when stuttering behaviours are studied. ldeally, stutters on words beginning with the same phoneme should be compared, rather than stutters on words beginning with any phoneme. The consideration of stuttering on different phonemes has particular relevance for therapy.

\section{ADDITIONAL PROBLEMS FOK RESEARCH INTO THERAPY}

The difficulties presented above have dealt specifically with studies of stuttering behaviour. There are additional hazards encountered by the researcher who is interested in research on etiology and therapy facets, which are not within the purview of this paper.'Therapy, in particular, brings its own special difficulties when research is undertaken, including a multitude of patient and therapy variables. This probably explains in part the scarcity of documented research on therapy with stutterers.

\section{CONCLUSIONS}

What has gone before has highlighted some of the confusions which are still very real in the study of stuttering. There is a need to separate what is conjectured from what has been proved, and for an awareness of how great the quantum leap there often is between theory and fact, and fact and therapy. There is an even more basic need - to ensure that the facts, the data about stuttering, are unequivocal, and that each new piece of research can be seen as placing a valid and reliable block on the structure which will lead to an understanding of the distressing disorder of stuttering.

\section{REFERENCES}

Adams, M.R. Some common problems in the design and conduct of experiments in stuttering. Journal of Speech and Hearing Research, 41, 3-9, 1976.

Aron, M.L. The Effects of the Combination of Trifluorperazine and Amuliharlitione on Adult Stutterers. Ph. D. Thesis, University of the Witwatersrand, 1964.

Brown, S.F. A further study of stuttering in relation to various speech sounds. Ouarterly Journal of Speech, 24, 390-397, 1938.

Brutten, C.J. Stuttering: topography, assessment, and behavior-change strategies. In .j. Eisenson (Ed.), Stuttering: A Second Sijmposium. New York: Harper and Row, 1975.

Brutten, C.J. and Shoemaker D.J. The Modification of Stuttering. Englewood Cliffs, Prentice Ilall, 1967.

Curlee, R.F. and Perkins, W.H. (Eds.) Nature and Troutment of Stutter ing: new directions. San Diego: College-Hill, 1984.

Johnson, W. Measurements of oral reading and speaking rate and disfluency of college-age male and female stutterers and nonstutterers. Journal of Speech and Hearing Disorders, Momograph Supplement 7, 1-20,1961.

Johnson, W. and Brown, S.F. Stuttering in relation to various speech sounds. Quarterly Journal of Spech, 21, 481-496, 1935.

Marks Wahlhaus, M.Judges' agreement on auditory and visual aspects of stuttering. Journal of the Sonth African Logopedic Society. 26, 3 18, 1979 .

Marks Wahlhaus, M. Here I st and. Paper presented at the International Conference on Stuttering. University of the Witwatersratd, 1986.

Marks Wahlhaus, M. The Consistency of Stutering Behaviours Over Time. Ph.U. Thesis (submitted), 1990.

Perkins, W.H. Horizons and beyond: confessions of a carpenter. Seminars in Speech and Language. 6, 233-244, 1985. Van Riper, C.Speech Correction: Principles and Methods (4th edn). New
York: Prentice Hall, 1963.

Van Riper, C. The Nature of Stuttering ( 2 nd ed). Englewood Cliffs: Prentice Hall, 1982.

Wingate, M.E. A standard definition of stuttering. Journal of Spech and Hearing Disorders, 29, 484-489, 1964.

Wingate, M.E. Adaptation, consistency and beyond: I. I.imitations and contradictions. Joumal of Fuency Disorders. 11, 1-36, 1986.

Zimmerman, G.N. Articulatory dynamics of stutterers. In R.F. Curlee and W.I. Perkins (Eds). Nature and Treatment of Stuttering: Now Lirectors. San Diego: College-Hill, 1984.

Zimmerman, G.N., Smith. A. and Hanley. J.M. Stuttering in need of a unifying conceptual framework. Journal of Sperch anil Hearing Research, 46, 25-31, 1981 . 